\title{
Гнійно-некротична хірургічна оніхопатологія, авторські погляди: деякі проблеми діагностики та комплексного лікування ускладнених та комбінованих випадків
}

\begin{abstract}
Мета роботи: покращити ефективність комплексного лікування хронічної та комбінованої гнійно-некротичної патології дистальних відділів кисті та стопи, зокрема “хірургічної оніхопатології”, шляхом оптимізації клінічної діагностики, розробки і вибору послідовності застосування окремих методик комплексного хірургічного лікування, створення ефективних протирецидивних заходів та профілактики ускладнень.

Матеріали і методи. Роботу виконано на клінічних базах Львівського національного медичного університету імені Данила Галицького. За 15-річний період (2006-2020рр.) у 1838 хворих віком від 5-92 років: 1007 чоловіків і 831 жінок досліджені нозологічні форми, клінічні варіанти та особливості перебігу патологічного процесу. Проспективно досліджено 757 випадків оніходеструкції. Клінічний та морфологічний матеріал опрацьовано методами описової та кореляційної статистики. Дизайн досліджень передбачав дотримання принципів конфіденційності та поваги до особистості хворого, концепцію інформованої згоди та інші положення морально-етичних норм та принципів біоетики.

Результати досліджень та їх обговорення. Найбільше спостережень немікотичної та мікотично-асоційованої гнійно-некротичної хронічної та комбінованої патології кисті та стопи припадала на субвибірки осіб середнього віку. Розподіл за віком демонстрував превалювання (у загальній кількості) осіб середнього та похилого віку, особливо у субвибірках із мікотичним дерматофітним (трихофітним) ураженням. У пацієнтів (у вікових групах 50-70 років) з наявністю врослого нігтя та піднігтьового гіперкератозу було діагностовано вторинне вростання нігтя внаслідок компресії гіперкератоїдними масами та дерматофітомою центральної частини нігтя, деформацію й інкарнацію. Стверджено 45,05 \% випадків вростання нігтя та 21,87 \% - ускладненого дерматофітійного оніхомікозу. Такі варіанти оніходеструкції, як і поліоніхомікоз, характерні для осіб похилого та старечого віку $\left(\chi^{2}=24,12\right.$, $\mathrm{p}=0,028)$. Найбільше становили особи з ускладненим оніхомікозом $\left(x^{2}=20,87, \mathrm{p}<0,01\right)$, діагностовано вторинну деформацію мікотично зміненого нігтя, $\chi^{2}=17,35, p=0,022$, вростання країв нігтя у епоніхеальні валики, $\chi^{2}=15,36, p<0,05$. У $48 \%$ спостережень констатовано мікотичне ураження однієї, у 27 \% - двох, в інших - 25 \% парціальної проспективної вибірки - більше 2 нігтьових пластинок. При проведенні патоморфологічного дослідження симультанно вивчено та конкретизовано ускладнений, торпідний, хронічний, а також рецидивний варіанти перебігу гнійно-некротичної патології кисті та стопи, пато- та морфогенез деструктивного оніхомікозу. Приєднання до мікотичної “хірургічної оніхопатології” бактерійної суперінфекції детермінує формування мало- або безсимптомного піднігтьового панариція змішаної етіології. Вторинний хронічний остеомієліт дистальної фаланги діагностовано у 5 \% усіх випадків, лікованих стаціонарно. Чимало незадовільних результатів лікування при комбінованих ураженнях детермінується неадекватним вибором або технічними порушеннями операційного лікування, у випадках залишення спікули та невдалій резекції $\left(x^{2}=4,22\right)$, рецидиви спостерігають при видаленні нігтів за способом Дюпюїтрена та інших відомих хірургічних методах $\left(\mathrm{x}^{2}=13,47, \mathrm{p}=0,02\right)$, при відмові від проведення одночасних хірургічних втручань на пароніхеальних і піднігтьових структурах. Операційне лікування повинне влючати протиінкарнаційні корекційні заходи, $\chi^{2}=12,11, p=0,024$; що дає змогу значно зменшити ризик рецидивів, $\chi^{2}=28,17, \mathrm{p}<0,01$. Запропоновано та впроваджено блокоподібну епоніхектомію, способи малотравматичної мобілізації та дисекції уражених нігтів. Максимальну частоту рецидивів поліоніхомікозу спостерігали впродовж 12-15 місяців, $\chi^{2}=25,52, p=0,018$, у разі системної терапії - на третій рік після лікування, $\chi^{2}=13,47, p=0,023$. Видалення уражених нігтів у хворих на деструктивний ускладнений оніхомікоз, комбіновані ураження доцільно проводити через оніхолізовані структури.
\end{abstract}

Ключові слова: гнійно-некротична оніхопатологія; оніхомікоз; інкарнації нігтів; комбіновані ураження; морфогенез; ускладнення; комплексне хірургічне лікування.

Постановка проблеми і аналіз останніх досліджень та публікацій. Профілактика та лікування хронічної та комбінованої некротичної патології кисті і стопи, зокрема панариція та його ускладнень, є однією з найбільш складних і недостатньо вивчених проблем гнійної хірургії [1-3, 13, 17], хоча цьому питанню присвячено чимало спеціальних досліджень [8, 11-13]. Сприятливим фоном для виникнення уражень дистальної фаланги, зокрема нігтів, їх вростання і гнійних оніхій $€$ облітеруючі захворювання артерій нижніх кінцівок, цукровий діабет $[1,3,10,13]$, системні захворювання сполучної тканини, порушення інервації $[6,11,17]$. Середня тривалість лікування хворого з підшкірним панарицієм становить 14,3 дня, піднігтьовим - 15,6, кістковим - 30,1, сухожилковим - 26,1, суглобовим - 25,2, пандактилітом - 27,1 дня [1-3, 15]. Врослий ніготь - патологічна хронічна компресія та інкарнація (“врізання”, “вростання”) нігтьової пластини в навколонігтьо- 
вий (епоніхеальний) валик [5-9], що детермінує розвиток у ньому хронічного гнійно-некротичного запалення [6, 7, 9, 14], з формуванням вогнищевих некрозів і гіпергрануляцій [16-18, 19, 22]. Як відомо, інкарнації нігтів і ускладнення грибкових уражень нігтьових пластин, що призводять до деформації і вростання, констатують в більш ніж половини хворих з хірургічною патологією кінцевих (нігтьових) фаланг пальців - в 63 \% спостережень $[8,12,14,15]$. Здебільшого уражається I палець (галюкс) лівої стопи [9, 12, 16, 19]. Ускладнений, торпідний, хронічний, а також - рецидивний варіанти перебігу захворювання констатують у 1227 \% хворих із гнійно-некротичними процесами кисті та стопи [3, 6, 7, 9, 12]; ускладнення, які погіршують якість життя пацієнтів $[1,3,8,19]$ та можуть стати причиною інвалідності діагностують у 0,5-3 \% [10, 11, 14, 15, 18]. Загалом деструктивні мікотичні ураження превалюють в осіб середнього та похилого віку [10-14], а в пацієнтів старечого віку “хірургічна оніхопатологія” становить половину всіх спостережень гнійно-некротичних хронічних уражень дистальних відділів кисті та стопи $[9,10,14,15,17]$. Найефективнішими методами системної антимікотичної терапії вважаємо пульс-терапію ітраконазолом $[12,17]$ або тербінафіном; застосування антимікотичних лініментів у післяопераційному періоді $[14,15,20,21]$ та протигрибкових лаків, що особливо показане у комплексному лікуванні деструктивного поліоніхомікозу, включно поєднані випадки з виникненням оніхокриптозу [2, 3, 13-15]. Комплексне лікування гнійної оніхеальної патології передбачає хірургічний етап - резекцію або видалення нігтя, некректомію, розкриття та дренування гнійних вогнищ [1, 3, 15], при необхідності - санацію кісткових уражень, консервативне лікування мікотичних i супутніх коморбідних процесів [1, 9, 17, 19-22].

Мета роботи: покращити ефективність комплексного лікування хронічної та комбінованої гнійно-некротичної патології дистальних відділів кисті і стопи, зокрема "хірургічної оніхопатології”, шляхом оптимізації клінічної діагностики, розробки та вибору послідовності застосування окремих методик комплексного хірургічного лікування, створення ефективних схем протирецидивних заходів та профілактики ускладнень.

Матеріали і методи. Роботу виконано на клінічних базах Львівського національного медичного університету імені Данила Галицького - інституту клінічної патології, кафедри сімейної медицини; хірургічному, ревматологічному та ендокринологічному відділеннях, відділенні паліативної допо- моги комунального некомерційного підприємства “4 міська клінічна лікарня м. Львова”, хірургічних відділень 2 та 5 Львівських комунальних міських поліклінік. До проведення комплексного дослідження залучено матеріально-технічні ресурси вищеназваних кафедр, рентгенологічних відділень, біохімічних лабораторій та бактеріологічної лабораторії 2 комунальної поліклініки м. Львова. За 15-річний період (2006-2020рр.) у 1838 хворих, віком від 5-92 років: 1007 чоловіків і 831 жінок досліджено нозологічні форми, клінічні варіанти та особливості перебігу патологічного процесу. Проспективно досліджено 757 випадків оніходеструкції: 400 чоловіків та 357 жінок. Вік прооперованих хворих - від 5 до 92 років. Мікотичні ураження становили половину всіх спостережень; випадки інкарнацій та оніхокриптозу - 22 \% вибірки. Ретроспективний матеріал становив 1081 спостережень деструктивної гнійно-некротичної патології кисті та стопи: 607 чоловіків та 474 жінок та був розділений на статистичні сукупності. Вік хворих становив від 11 до 85 років. Усім пацієнтам проведено адекватне комплексне лікування, що включало терапію коморбідної патології, хірургічну санацію патологічних вогнищ (при необхідності багаторазову) згідно з загальноприйнятими рекомендаціями [1, 3, 11, 13-15], антибіотико- та антимікотикотерапію [2, 10, 15-17, 20], дерматологічне лікування мікотичних уражень [11, 12]. Клінічний та морфологічний матеріал, випадки “хірургічної оніхопатології” опрацьовано методами описової та кореляційної статистики [2, 13-16]. Довірювальний інтервал становив 95 \%, для аналізу кількісних величин використовували метод Пірсона; для якісних - метод Спірмена, визначали $\chi^{2}$ ступінь впливу етіологічних чинників, морфогенезу та ефективністю лікування та рівень значимості, показник $p$ у досліджуваних клінічних варіантах [15]. Достовірність зміни показників при $\mathrm{p} \leq 0,05$ до та після лікування визначали за регресійним аналізом ANOVA. Достовірність зміни показників до- та після лікування проводили пакетами математичної обробки вільнодоступного програмного забезпечення. Дизайн досліджень передбачав дотримання принципів конфіденційності та поваги до особистості хворого [15, 19, 21], концепцію інформованої згоди, врахування переваг користі над ризиком шкоди $[1-3,15]$ та інших етичних принципів стосовно людей, які виступають суб'єктами досліджень. Дослідження проведено 3 дотриманням принципів Гельсінської декларації прав людини, Конвенції Ради Європи про права людини і біомедицину (2007) та рекомендацій Комітету з біоетики при Президії НАМН України 


\section{З ДОСВІДУ РОБОТИ}

(2002). Комісією 3 питань біоетики Львівського національного медичного університету імені Данила Галицького не виявлено порушень морально-етичних норм при проведенні досліджень, протокол № 8 від 18.09.2017 р.

Результати досліджень та їх обговорення. Найбільше спостережень немікотичної та мікотично-асоційованої гнійно-некротичної хронічної та комбінованої патології кисті та стопи припадало на субвибірки осіб середнього віку $[11,12,14$, 15]. Розподіл за віком демонстрував превалювання (у загальній кількості) осіб середнього та похилого віку, особливо у субвибірках із мікотичним дерматофітним (трихофітним) ураженням. Констатовано, що панарицій та первинний оніхокриптоз (врослий ніготь) частіше уражав осіб працездатного віку [12]. Панарицій домінував в осіб середнього віку, тоді як врослий ніготь - у пацієнтів віком до 40 років. Незважаючи на представлений розподіл домінуючих нозологічних форм у загальній субвибірці, справжня частота випадків панариція була значно вищою, включала ускладнені та комбіновані випадки інших субвибірок, загалом становила 950 клінічних спостережень. 3 них у 766 хворих спостерігалися поверхневі, у інших 184 - глибокі форми гнійно-некротичного ураження. Кількість випадків гнійних кандидозних та змішаних (кандидозно-бактерійних) оніхій [9, 10, 13-15] наростала поступово та рівномірно, досягаючи максимуму в субвибірці 61-70-річних хворих без ознак “пікового” домінування частоти даних клінічних варіантів. За чисельністю спостережень оніхопатології в загальному матеріалі однозначно переважали хворі із врослим нігтем та ускладненим дерматофітійним мікозом [7, 10, $14,15]$. Пацієнти цих субвибірок становили понад $65 \%$ загальної вибірки. Загалом діагностовано 827 випадків врослого нігтя та 401 - дерматофітійного мікозу. Пацієнтів із панарицієм (гнійною оніхією) та кандидозним оніхомікозом відповідно було виявлено 184 та 176 випадків. У пацієнтів (у вікових групах 50-70 років) із врослим нігтем та піднігтьовим гіперкератозом було діагностовано вторинне вростання нігтя внаслідок компресії гіперкератоїдними масами та дерматофітомою [4, $10,11,13]$ центральної частини мікотично зміненого нігтя, що детермінувало його деформацію та супроводжувалося вростанням країв нігтя в епоніхеальні валики $[12,15]$. У цих же субвибірках було констатовано зростання частоти ускладнених та поєднаних оніхеальних уражень $[11,12]$. 3 моменту виникнення перших ознак захворювання в перші три дні по медичну допомогу з приводу гострих процесів звернулися 11,8 \% (парціальної субвибірки) хворих, впродовж 7 днів - 34 \% пацієнтів, до двох тижнів - 17,4 \% осіб, інші хворі - через два тижні від початку захворювання.

За кількістю спостережень у загальному матеріалі однозначно переважали хворі з інкарнованим дерматофітійним оніхомікозом. Пацієнти цих субвибірок становили понад 65 \% загальної вибірки. Загалом діагностовано 45,05 \% випадків вростання нігтя та 21,87 \% - дерматофітійного оніхомікозу. Пацієнтів із панарицієм (гнійною оніхією) [1, 3, 9-11] та кандидозним оніхомікозом відповідно було виявлено 92 та 87 випадків. Серед немікотичної деструктивної хірургічної оніхопатології превалював оніхокриптоз [19, 22], що у парціальній сукупності клінічних спостережень становив 414 випадків (45,05 \%), $x^{2}=24,12, p=0,028$. Пікову частоту негрибкових уражень нігтів спостерігали в осіб третьої субвибірки - віком 30-40 років, що найбільше візуалізувалося у субвибірці хворих на інкарнацію нігтьових пластин. Серед субвибірок пацієнтів із панарицієм та оніхеальною травмою таких різких домінувань частоти не спостерігали, проте спостерігали незначне домінування у субвибірках: осіб 30-40 років із панарицієм та в осіб віком до 30 років - 3 оніхеальною травмою. У субвибірках за віком хворих із хірургічною оніхопатологією понад половину всіх спостережень становили пацієнти середнього віку - 30-60 років. 3 них 17 \% спостережень від загальної вибірки становили особи віком 30-40 років та інші $17 \%$ - пацієнти віком 40-50 років; $16 \%$ - хворі віком 50-60 років. $15 \%$ випадків хірургічної оніхопатології становили особи віком 60-70 років, 13 \% - хворі 20-30-річного віку. Стверджено, що неускладненим оніхокриптозом переважно уражаються особи молодого віку, $\chi^{2}=24,12, p=0,028$; наявне зростання частоти інкарнацій нігтя та піднігтьового гіперкератозу, оніхогрифозу, дерматофітом та інших мікотичних оніхій $(\mathrm{p}=0,012)[3,4,10-15,20-21]$, що можуть бути причиною мікотичного остеомієліту дистальної фаланги. Такі варіанти оніходеструкції, як і поліоніхомікоз, характерні для осіб похилого та старечого віку $[9,14,15,17,20,21]\left(\chi^{2}=24,12\right.$, $\mathrm{p}=0,028)$. Найбільшу кількість становили особи 3 ускладненим оніхомікозом $\left(x^{2}=20,87, p<0,01\right)$, діагностовано вторинну деформацію мікотично зміненого нігтя, $\chi^{2}=17,35, p=0,022$, коефіцієнт Спірмена ( $\rho$ ) у дослідних групах 0,552-0,617, що супроводжувалося вростанням країв нігтя в епоніхеальні валики, $\chi^{2}=15,36, p<0,05$.

Кістковий панарицій або остеомієліт фаланг пальців констатовано у 5 \% усіх випадків, лікованих стаціонарно. У 93,2 \% спостережень за- 
хворювання виникало при переході запалення 3 навколишніх тканин [1, 3, 9-11]. Первинне інфікування кісток фаланг пальців виникало при їх безпосередніх ушкодженнях та констатовано у інших 7 \% хворих. Рентгенологічно констатували 3 типи секвестрації нігтьової фаланги: крайову секвестрацію з утворенням обмеженої крайової деструкції у вигляді дрібного секвестру виявлено у 82 \% парціальних спостережень секвестрації в терміни 12-14 днів з початку ураження; субтотальне ураження нігтьової фаланги з деструкцією головки і тіла кісток при збереженні епіфізарного відділу діагностовано в терміни 18-20 днів 12 \% парціальної вибірки; тотальну секвестрацію нігтьової фаланги 3 проривом гною в суглоб, що спостерігалася найчастіше в терміни 1,5-3 місяці та була наслідком пізньої діагностики та неадекватного лікування - в інших 6 \% випадків остеомієліту фаланги пальця [11, 13-15]. Операції при кістковому панариції ми проводили як широке розкриття гнійного вогнища $з$ видаленням секвестрів або ділянок зруйнованої кістки через розтин Клаппа або Фішмана - Усольцевої, при мікотичних остеомієлітах - переднім напівовальним трансоніхеальним доступом через нігтьове ложе $[11,12,15]$. Результати лікування кісткового панариція залежали від якості проведеної операції, раціональної терапії [1-3]; проте у 23 \% осіб 3 остеомієлітом фаланги ми вимушено провели ампутацію фаланги та у 4 \% - ураженого пальця $[1,3,15]$. При нераціональному лікуванні поверхневих форм панариція у 3 \% пацієнтів спостерігали ускладнення у вигляді кістково-суглобового панариція, розвитку вторинного тендовагініту, поширеного некрозу м'яких тканин, пандактиліту $[1,3,4]$. Недосконалість хірургічних методик становить понад половину причин рецидивів, включно випадки вростання з піднігтьовим гіперкератозом або оніхогрифозом, $\mathrm{x}^{2}=20,13, \mathrm{p}<0,01$. У 42 \% пацієнтів (парціальної вибірки) констатовано неускладнений врослий ніготь 3 незначно вираженими інфільтративними змінами епоніхеального валика [5-9, 12]. У інших хворих діагностовано наявність ускладнень, у 39 \% хворих візуалізовано хронічне запалення з формуванням вогнищевих некрозів та епоніхеальних гіпергрануляцій [8-10, 12, 16, 18, 19]; в інших 19 \% вибірки виявлено гострий епоніхеальний абсцес $[1,3$, $6,9,22]$.

Основною патологічною структурою деструктивного оніхомікозу є піднігтьовий гіперкератоз [9, 13-15], який характеризується наявністю патологічного надлишкового “ороговіння” та деформацією нігтів, запропоновано способи мобілізації та видалення нігтьової пластини при неускладненому мікотичному піднігтьовому гіперкератозі [14, 15, 17]. До деструктивних та ускладнених форм оніхомікозу, випадків “хірургічної оніхопатології” та комбінованих мікотичних уражень було віднесено піднігтьовий гіперкератоз, оніхогрифоз (рис. 1,2 ) з оніхолізисом [15, 17] і формуванням піднігтьового панариція та гнійну мікотичну пароніхію $[12,14]$. Захворювання характеризувалися помірно вираженим больовим синдромом.

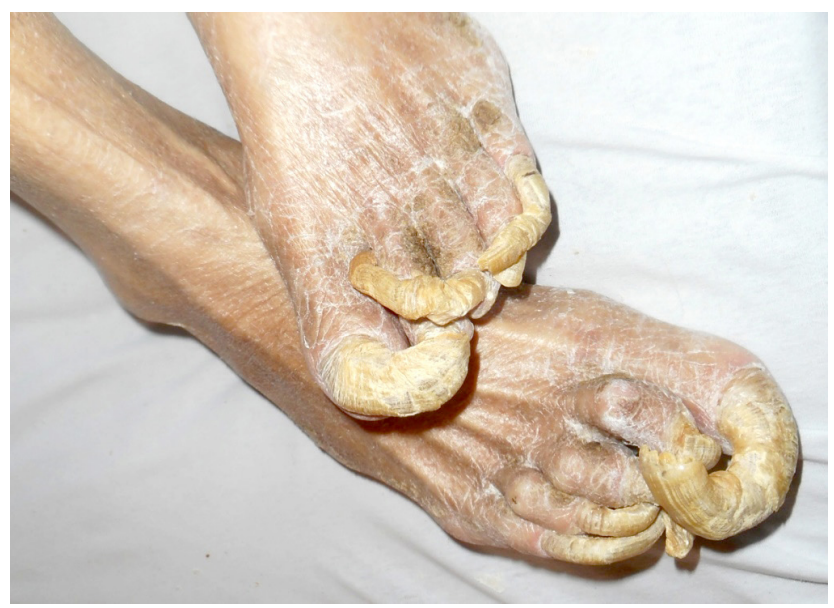

Рис. 1. Випадок деструктивного поліоніхомікозу 3 множинними вторинними інкарнаціями: трихофітійний гігантський оніхогрифоз нігтьових пластин у хворого М., 83 роки. Інтраопераційна фотофіксація, тильна проекція. Відділення паліативної допомоги 4 міської клінічної лікарні м. Львова, 15. 05. 2020 р.

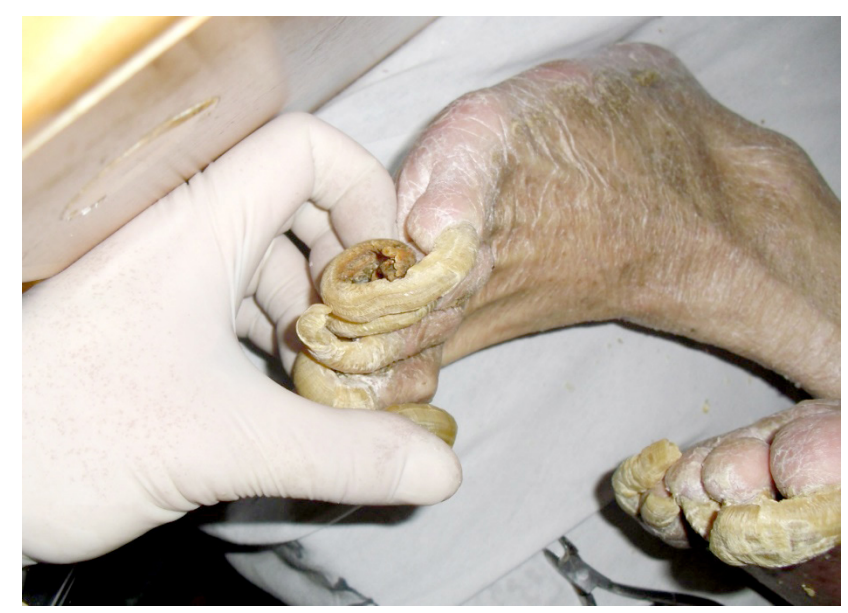

Рис. 2. Випадок деструктивного поліоніхомікозу 3 множинними вторинними інкарнаціями: трихофітійний гігантський оніхогрифоз нігтьових пластин у хворого М., 83 роки. Інтраопераційна фотофіксація, бокова проекція. Відділення паліативної допомоги 4 міської клінічної лікарні м. Львова, 15. 05. 2020 р. 


\section{З ДОСВІДУ РОБОТИ}

Патологічні зміни нігтьової пластинки полягали в гіпертрофії й деформації нігтя [3, 4, 9-11, 13-15], поверхневих патологічних нашаруваннях на нігтьовому ложі (бурого кольору 3 розпадом) та формуванні множинних гнійних бактерійно-мікотичних вогнищ з абсцедуванням (у вигляді “бджолиних сот”) [4, 10, 13, 15]. У 48 \% спостережень констатовано мікотичне ураження однієї, у 27 \% - двох, у інших 25 \% парціальної проспективної вибірки - більше 2 нігтьових пластинок. При проведенні патоморфологічного дослідження симультанно вивчено та конкретизовано ускладнений, торпідний, хронічний, а також - рецидивний варіанти перебігу гнійно-некротичної патології кисті та стопи, пато- та морфогенез деструктивного оніхомікозу. Для піднігтьового гіперкератозу характерне зливне ураження субоніхеального простору [11, 14, 20, 21], діагностовано формування комбінованих уражень $[10,13$, 15] на фоні поліоніхомікозу [14, 15, 17] (рис. 2), $\mathrm{X}^{2}=20,13, \mathrm{p}<0,01$. У осіб з деструктивним оніхомікозом застосовано комплекс рентгенологічного, бактеріологічного та мікологічного обстеження. 3 уражених нігтів найчастіше виділяли Т. rubrum (85 \% парціальної вибірки) та Т. mentagrophytes, а також - C. albicans.

У хворих, крім піднігтового гіперкератозу та (або) оніхогрифозу, у низці випадків була наявна центральна деструкція нігтьової пластини з захопленням у некротичний процес дерматофітоми та фрагмента нігтьового ложа. У 35 клінічних спостереженнях констатовано специфічну симптоматику. Дані зміни поєднувалися 3 наявністю виражених множинних деформацій нігтів (рис. 3), гнійних виділень з-під нігтьової пластини та 3 епоніхеальних “каналів”, констатовано також наявність гіпергрануляцій $[3,6,7,9,13,14]$. Захворювання характеризувалось тривалим анамнезом, специфічним морфогенезом, виникненням хронічної пароніхії на фоні трихофітного піднігтьового гіперкератозу (рис. 4), що супроводжувалося посиленням больового синдрому та появою гнійних виділень 3-під нігтя; вираженим набряком та гіперемією без візуалізації симптому патологічної флотації (рис. 3, 4).

Рентгенологічно діагностовано остеомаляцію субоніхеального фрагмента дистальної фаланги 3 відшаруванням періосту та вираженим остеопорозом інших ділянок кістки. Інтраопераційно був підтверджений кістковий панарицій змішаної етіології (трихофітно-кандидозно-бактерійного походження) - остеомієліт фаланги пальця з формуванням гнійної нориці через оніхолізовані структури, піднігтьовий гіперкератоз та дерматофітому. На

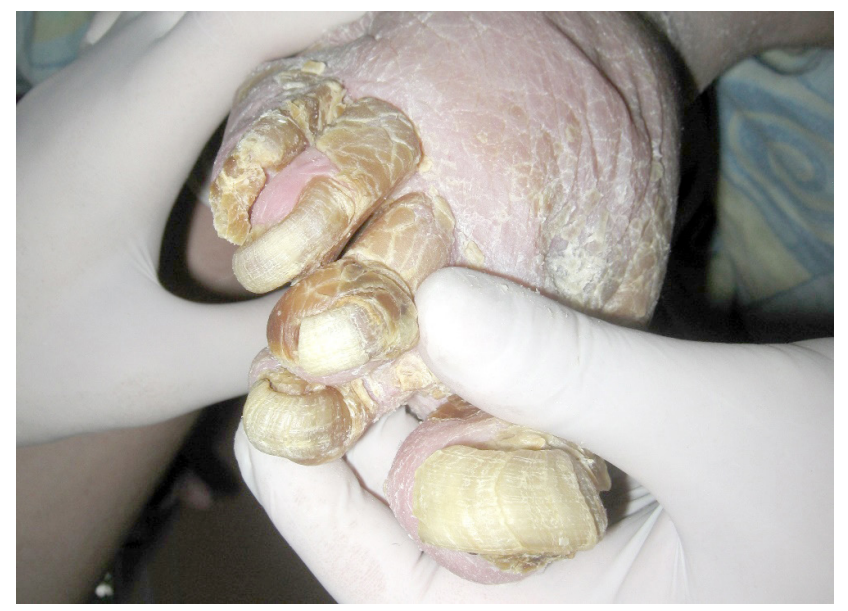

Рис. 3. Клінічне спостереження сквамозно-гіперкератозного варіанту трихофітії нігтів та шкіри обох стоп з локальними некрозами м'яких тканин, деструктивного руброоніхомікозу, поліоніхогрифозу, хронічної мікотичної пароніхії. Нігті потовщені, деформовані у вигляді “баранячих рогів”. Гнійна оніхія I, II, III та V пальців правої стопи у хворого Л., 72 роки. Відділення паліативної допомоги 4 міської клінічної лікарні м. Львова, 23. 06. 2021 р.

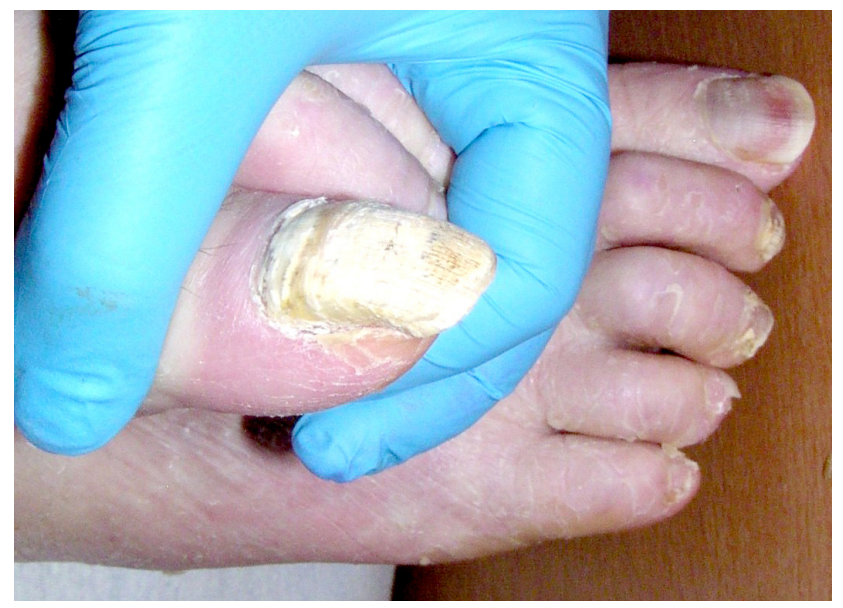

Рис. 4. Випадок ментагрофітозу нігтя, оніхогрифозу. Формування комбінованих уражень на фоні мікотичного ураження I пальця - піднігтьового гіперкератозу 3 субунгвальною деструкцією, двобічного вростання нігтя, дерматофітоми у хворої Г., 89 років. Хронічна мікотична пароніхія I пальця лівої стопи. Спонтанний субтотальний мікотично-бактерійний оніхолізис із некрозом ділянки нігтьового ложа. Синдром патологічної флотації нігтя відсутній за рахунок двобічної інкарнації. Відділення паліативної допомоги 4 міської клінічної лікарні м. Львова, 25.06.2021 р.

основі аналізу вищеописаної клінічної картини мікотично-асоційованого остеомієліту дистальної фаланги сформульовано класичну тріаду ознак для 
його клінічної діагностики: 1) помірно-виражений біль у дистальний фаланзі, що посилюється при натисканні на пучку пальця; 2) наявність деструктивного піднігтьового гіперкератозу з оніхолізисом та центральним некрозом дерматофітоми; 3) тривало існуючі гнійні виділення з епоніхеальних “каналів” та субоніхеально - з-під некротизованих ділянок дерматофітоми $[4,10]$. Таким чином приєднання до “хірургічної оніхопатології” та комбінованих уражень бактерійної суперінфекції детермінує формування мало- або безсимптомного піднігтьового панариція змішаної етіології (гнійні вогнища множинні, у вигляді “бджолиних сот”). Цей варіант піднігтьового панариція внаслідок особливостей клінічного перебігу (мало- або безсимптомного) нерідко діагностується та лікується несвоєчасно та у 0,5 \% парціальних спостережень оніхопатології $є$ причиною періоститу та кісткового панариція - остеомієліту дистальної фаланги пальця внаслідок поширення інфекції з ложа нігтя на періост та нігтьову фалангу [1, 3].

У попередніх дослідженнях $[14,15]$ стверджено, що чимало незадовільних результатів при комбінованих ураженнях з мікотичною оніхопатологією стверджено при неадекватному виборі або технічних порушеннях операційного лікування (табл. 1), у випадках залишення спікули та при невдалій резекції $\left(x^{2}=4,22\right)$, рецидиви спостерігають при видаленні нігтів за способом Дюпюїтрена та інших відомих хірургічних методах $\left(x^{2}=13,47\right.$, $\mathrm{p}=0,02)$, відмові від проведення одночасних хірургічних втручань на пароніхеальних і піднігтьових структурах при комбінованих ураженнях, пов'язаних з мікозами, особливо при неврахуванні морфологічних змін мікотичного піднігтьового гіперкератозу, $x^{2}=22,18, \mathrm{p}<0,01$, що відповідає даним літератури $[12,13]$. Також до виникнення рецидивів призводить носіння тісного взуття в ранньому післяопераційному періоді, травматичні ушкодження нігтьової фаланги та некорегована ортопедична патологія [3, 10, 11, 13-15].

Впроваджено методи лікування "хірургічної оніхопатології” - хронічної та комбінованої патології нігтьової фаланги - дистальних відділів кисті та стопи $[7,8,12,14-16,22]$, новий спосіб хірургічного доступу для виконання крайової резекції нігтя при ускладненому оніхокриптозі, що являє собою блокоподібну епоніхектомію $[14,15$, 22] та застосовується як експлоративний доступ при ускладненій компресійній оніхопатології [12, $15,19]$.

Вважаємо, що повноцінне операційне лікування “хірургічної оніхопатології” при наявності вростання нігтя повинно бути декомпресійним (шляхом виконання резекції чи видалення нігтя усувати патологічну компресію епоніхеальних тканин) та містити профілактичний (запобігати виникненню рецидивів вростання) компонент [3, 6, 7] $\chi^{2}=12,11$, $\mathrm{p}=0,024$; що дає змогу значно зменшити ризик рецидивів (відповідно, 3,25 \% та 6,42 \%); $\chi^{2}=28,17$, $\mathrm{p}<0,01[6,7,12,16,18,19]$. Двокомпонентні методи (резекція, або видалення нігтя (екстирпація чи абляція нігтьової пластини), доповнена висіченням зміненого епоніхія, розкриттям, некректомією і дренуванням гнійних вогнищ; також крайова резекція чи видалення нігтьової пластини, доповнена парціальною матриксектомією) [5-8, 16] $є$ протирецидивними: висічення патологічно змінених епоніхеальних тканин елімінує субстрат для “вростання” (епоніхеальний валик) [6, 14, 15, 22], детермінує прецизійну дисекцію [16, 18, 22], зниження травматичності маніпуляцій, зменшення ризику ушкодження нігтьового ложа та навколишніх структур у контексті профілактики

Таблиця 1. Оцінка ступеня впливу різних чинників на рецидив інкарнації нігтя (виникнення реоніхокриптозу) після операційного лікування

\begin{tabular}{||l|c|c|c||}
\hline \multicolumn{1}{|c|}{ Чинники ризику } & Частота, \% & $x^{2}$ & p \\
\hline Вид первинного операційного втручання або наявність спікули & 88 & 13,47 & 0,02 \\
\hline Технічні порушення хірургічного лікування & 53 & 4,22 & 0,0465 \\
\hline Носіння тісного взуття в ранньому післяопераційному періоді & 41 & 5,49 & 0,016 \\
\hline Травма пальця після операції & 11 & 12,21 & 0,006 \\
\hline Некоректована ортопедична патологія & 47 & 5,44 & 0,0147 \\
\hline Наявність гнійного процесу & 23 & 12,37 & 0,021 \\
\hline Нелікований оніхомікоз & 65 & 11,03 & 0,022 \\
\hline \hline
\end{tabular}




\section{З ДОСВІДУ РОБОТИ}

поширення гіфів збудника у навколонігтьових тканинах у контексті виникнення рецидивів мікозу та ускладнень, а часткова крайова ексцизія матриксу нігтя звужує нігтьову пластину, запобігаючи повторному вростанню; що дає змогу зменшити кількість рецидивів (відповідно 3, 25 \% та 6,42 \%) [14, 16]; тому такі операції ми вважаємо умовно-радикальними з протирецидивним компонентом. Трикомпонентне операційне лікування (резекція або екстирпація нігтя, доповнена висіченням патологічно змінених епоніхеальних тканин та прецизійною парціальною матриксектомією) [5, 11-13] $€$ найбільш ефективним для хірургічної корекції врослого нігтя, тому що практично не супроводжується виникненням рецидивів “вростання”; тому його можна вважати радикальним [11, 12]. Після епоніхектомії під мобілізований край нігтя поетапно вводили сокироподібний наконечник стерильної лопатки манікюрної РЕ-10/2 (скруглений пушер із сокироподібним распатором), стерильний пушер (рис. 5), педикюрний інструмент PE-60/1, якими поетапно мобілізували нігтьову пластину маятникоподібними рухами до росткової зони та проксимального краю деформованого нігтя, поетапно видаляючи вишкрібанням гіперкератоїдні маси стерильною лопаткою манікюрною PE-10/2 та малою ложечкою Фолькмана, мобілізуючи та припіднімаючи нігтьову пластину. При технічній неможливості швидкої мобілізації нігтя пушером, распатором через оніхолізовані структу-

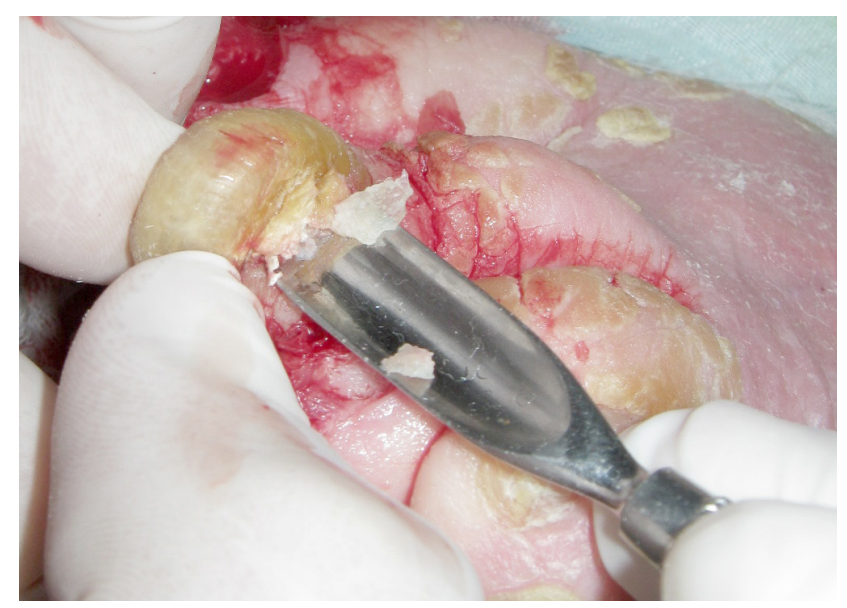

Рис. 5. Випадок сквамозно-гіперкератозного варіанту трихофітії нігтів та шкіри обох стоп із некрозами м'яких тканин, деструктивного руброоніхомікозу, поліоніхогрифозу. Операція - видалення змінених нігтьових пластин. Етап малотравматичної мобілізації пушером оніхогрифозно змінених нігтьових пластин пальців лівої стопи у хворого Л., 72 роки. Відділення паліативної допомоги 4 міської клінічної лікарні м. Львова, 23. 06. $2021 \mathrm{p}$. ри формували канал, тупим шляхом послідовними рухами відділяли змінену нігтьову пластину в контрлатеральному напрямку, протилежному стороні вростання. Нігтьову пластину фіксували затискачем, резектували або видаляли. Виконували парціальну матриксектомію [5, 11, 12]. Висікали та діатермокоагулювали матрикс нігтя в ділянці вростання [5, 7-9].

Розроблено авторські способи хірургічних втручань, що базуються на малотравматичній мобілізації та резекції/видалення уражених нігтів через оніхолізовані структури $[9,13,17]$, детермінують зменшення інтраопераційного ушкодження нігтьового ложа $[6-8,14],\left(\chi^{2}=20,13, p<0,01\right)$, зменшують ризик мікотичного забруднення інших прилеглих структур $\left(\mathrm{x}^{2}=27,41, \mathrm{p}<0,01\right)$; характеризуються зменшенням інтенсивності болю $[11,12$, $14-16]\left(x^{2}=48,32, p<0,01\right)$, статистично значимим збільшенням швидкості загоєння рани.

У випадках ускладненого інкарнованого оніхомікозу ми вважаємо оптимальною процедурою втручання малотравматичне видалення нігтів або резекцію нігтів із мобілізацією через блокоподібний епоніхектомічний розтин. Найефективнішими методами антимікотичної терапії $є$ пульс-терапія ітраконазолом [14, 15, 20, 21] або тербінафіном [2, $7,15]$, комбіноване застосування антимікотичних лініментів та лаків [15, 20]. У прооперованих за нашими методиками пацієнтів спостерігали зменшення інтенсивності патологічного процесу та больового синдрому, скорочення термінів загоєння ранових поверхонь на 4-7 днів і термінів тимчасової непрацездатності - на 3-4 дні порівняно зі стандартними методиками видалення патологічно змінених нігтьових пластин. Максимальну частоту рецидивів поліоніхомікозу спостерігали впродовж $12-15$ місяців, $\chi^{2}=25,52, \mathrm{p}=0,018$, у разі системної терапії - на третій рік після лікування, $\chi^{2}=13,47$, $\mathrm{p}=0,023$, у таких випадках нерідко виникали показання до повторних втручань, $\rho=0,511-0,791$. У деяких випадках ускладненого оніхомікозу та вростання нігтів ми вважаємо оптимальною процедурою втручання малотравматичне видалення нігтів, висічення дерматофітоми з частковою крайовою матриксектомією $\left(x^{2}=31,23, \mathrm{p}<0,01\right)$, що може значно зменшити кількість рецидивів (відповідно, 1-3 \% на ранніх стадіях 3,25 \% та 6,42 \% - в ускладнених та комбінованих випадках вростання; $\left.\chi^{2}=28,17, \mathrm{p}<0,01\right)$.

Висновки. Констатовано, що ускладнений, торпідний, хронічний, а також - рецидивний варіанти перебігу гнійно-некротичної патології кисті та стопи, випадки “хірургічної оніхопатології” 


\section{З ДОСВІДУ РОБОТИ}

та комбінованих уражень внаслідок особливостей морфології та патогенезу деструктивних форм оніхомікозу, піднігтьового гіперкератозу та оніхогрифозу детермінують впровадження особливих способів прецизійного хірургічного лікування, зокрема видалення уражених нігтьових пластин відповідно до зниження травматичності маніпуляцій, зменшення ризику ушкодження нігтьового ложа та навколишніх структур у контексті профілактики поширення гіфів збудника в навколонігтьових тканинах, виникнення рецидивів та ускладнень. Для хірургічного лікування оніхокриптозу доцільно застосовувати спосіб доступу до врослого краю нігтьової пластини - блокоподібну епоніхектомію, ефективність якої детермінується тотальною елімінацією зміненого епоніхія зі сторони вростання, створенням можливості для адекватного виконання резекції, чіткою візуалізацією росткової зони та матриксу для виконання парціальної матриксектомії, можливістю розширення доступу для ревізії субоніхеальних структур, включно дистальний кінець нігтьової фаланги. Видалення уражених нігтів у хворих на деструктивний ускладнений оніхомікоз, комбіновані ураження доцільно проводити через оніхолізовані структури, що, на нашу думку, відповідає вимогам малої травматичності.

\section{СПИСОК ЛІТЕРАТУРИ}

1. Abrams R. A. Hand infections: treatment, recomendations for specific tipes / R. A. Abrams, M. J. Botte // J. Am. Acad. Orthop. Surg. - 1996. - Vol. 4 (4). - P. 219-230.

2. Gilbert D. N. Sanford guide to antimicrobial therapy. - URL : https://www.sanfordguide.com/about/editorial-board/david-n-gilbert.

3. Davis J. H. Clinical Surgery / J. H. Davis. - Vol. 1. - St. Louis.Washington-Toronto: The C. V. Mosbi Compani, 1987. - 1024 p.

4. Goettmann S. Onychomatricoma with pterygium aspect: unusual clinical presentation / S. Goettmann, I. Zaraa, I. Moulonguet // Acta Derm. Venereol. - 2006. - Vol. 86 (4). - P. 369-370.

5. Farrelly P. J. Simple operative management of ingrown toenail using bipolar diathermy / P. J. Farrelly, J. Minford, M. O. Jones // Eur. J. Pediatr. Surg. - 2009. - Vol. 19 (5). - P. 304-306.

6. Haneke E. Controversies in the treatment of ingrown nails / E. Haneke // Dermatol. Res. Pract. - 2012. - Vol. 5. - P. 1-12.

7. Kim J. Y. Treatment of symptomatic incurved toenail with a new device / J. Y. Kim, J. S. Park // Foot Ankle Int. - 2009. Vol. 30 (1). - P. 1083-1087.

8. Kim M. Partial removal of nail matrix in the treatment of ingrown nails: prospective randomized control study between curettage and electrocauterization / M. Kim, I. G. Song, H. J. Kim // Int. J. Low Extrem. Wounds. - 2015. - Vol. 14 (2). - P. 192-195. 9. Morphologic study of normal, ingrown, and pincer nails / M. Kosaka, H. Kusuhara, Y. Mochizuki [et al.] // Dermatol. Surg. - 2010. - Vol. 36 (1). - P. 31-38.

10. Dermatophytoma: An under-recognized condition / C. Leeyaphan, S. Bunyaratavej, N. Prasertworanun [et al.] // Indian. J. Dermatol. Venereol. Leprol. - 2016. - Vol. 82 (2). - P. 188-189. 11. Stewart C. L. Update: nail unit dermatopathology / C. L. Stewart, A. I. Rubin // Dermatol. Ther. - 2012. - Vol. 25 (6). - P. 551-568.

12. Tsunoda M. Patient-controlled taping for the treatment of ingrown toenails / M. Tsunoda, K. Tsunoda // Ann. Fam. Med. 2014. - Vol. 12 (6). - P. 553-555.

\section{REFERENCES}

1. Abrams, R.A., \& Botte, M.J. (1996). Hand infections: treatment, recomendations for specific tipes. J. Am. Acad. Orthor. Surg., 4 (4), 219-230. DOI: 10.5435/00124635-199607000-00006.

2. Gilbert, D.N. Sanford guide to antimicrobial therapy. Retrieved from: https://www.sanfordguide.com/about/editorial-board/david-n-gilbert.
13. Tucker J. R. Nail deformities and injuries / J. R. Tucker // Prim. Care. - 2015. - Vol. 42 (4). - P. 677-691.

14. Vergun A. R. Destructive complicated onychomycosis with nail incarnation: case series, complex surgical treatment / A. R. Vergun // Bull. Sci. Res. - 2017. - Vol. 4. - P. 56-60.

15. Vergun A. R. Surgical nail pathology: some problems of diagnosis and complex treatment / A. R. Vergun // Qualifying scientific work on the rights of manuscripts: Doctor's thesis. - Lviv: Danylo Halytsky Lviv National Medical University of Ministry of Health of Ukraine, 2018. - 286 p.

16. Yabe T. A minimally invasive surgical approach for ingrown toenails: partial germinal matrix excision using operative microscope / T. Yabe, M. Takahashi // J. Plast. Reconstr. Aesthet. Surg. - 2010. - Vol. 63 (1). - P. 170-173.

17. Zaias N. Finger and toenail onycholysis / N. Zaias, S. X. Escovar, M. N. Zaiac // J. Eur. Acad. Dermatol. Venereol. - 2015. - Vol. 29 (5). - P. 848-853.

18. Zang K. A retrospective study of non-thermal laser therapy for the treatment of toenail onychomycosis / K. Zang, R. Sullivan, S. Shanks // J. Clin. Aesthet. Dermatol. - 2017. - Vol. 10 (5). P. 24-30.

19. Zavala Aguilar K. Management of onychocryptosis in primary care: A clinical case / K. Zavala Aguilar, F. Gutierrez Pineda, E. Bozalongo de Aragon // Semergen. - 2013. - Vol. 39 (6). P. 38-40.

20. Zecha M. Combination of amorolfine nail lacquer and oral itraconazole: a new approach for the treatment of severe onychomycosis / M. Zecha, M. Alsina, J. M. Tortes Rodriquez // JEADV. - 2001. - Vol. (5). - P. 67.

21. Zeichner J. A. Onychomycosis to fungal superinfection: prevention strategies and considerations / J. A. Zeichner // J. Drugs Dermatol. - 2015. - Vol. 14 (10). - P. 32-34.

22. Zeng M. Meliorated surgical procedure of Winograd for recurrent onychocryptosis / Zeng M., S. P. Fu // Zhonghua Yi Xue Za Zhi. - 2012. - Vol. 92 (25). - P. 1767-1769.

3. Davis, J.H. (1987). Clinical surgery. Vol. 1. St. Louis.-Washington-Toronto: The C. V. Mosbi Compani.

4. Goettmann, S., Zaraa, I., \& Moulonguet, I. (2006). Onychomatricoma with pterygium aspect: unusual clinical presentation. Acta Derm. Venereol., 86 (4), 369-370.

5. Farrelly, P.J., Minford, J., \& Jones, M.O. (2009). Simple op- 


\section{З ДОСВІДУ РОБОТИ}

erative management of ingrown toenail using bipolar diathermy. Eur. J. Pediatr. Surg., 19 (5), 304-306.

6. Haneke, E. (2012). Controversies in the treatment of ingrown nails. Dermatol. Res. Pract., 5, 1-12.

7. Kim, J.Y., \& Park, J.S. (2009). Treatment of symptomatic incurved toenail with a new device. Foot Ankle Int., 30 (1), 1083-1087. 8. Kim, M., Song, I.G., \& Kim, H.J. (2015). Partial removal of nail matrix in the treatment of ingrown nails: prospective randomized control study between curettage and electrocauterization. Int. J. Low Extrem. Wounds, 14 (2), 192-195.

9. Kosaka, M., Kusuhara, H., Mochizuki, Y., Mori, H., \& Isogai, N. (2010). Morphologic study of normal, ingrown, and pincer nails. Dermatol. Surg., 36 (1), 31-38.

10. Leeyaphan, C., Bunyaratavej, S., Prasertworanun, N., Muanprasart, C., Matthapan, L., \& Rujitharanawong, C. (2016). Dermatophytoma: An under-recognized condition. Indian. J. Dermatol. Venereol. Leprol., 82 (2), 188-189.

11. Stewart, C.L., \& Rubin, A.I. (2012). Update: nail unit dermatopathology. Dermatol. Ther., 25 (6), 551-568.

12. Tsunoda, M., \& Tsunoda, K. (2014). Patient-controlled taping for the treatment of ingrown toenails. Ann. Fam. Med., 12 (6), 553-555. 13. Tucker, J.R. (2015). Nail deformities and injuries. Prim. Care, 42 (4), 677-691.

14. Vergun, A.R. (2017). Destructive complicated onychomycosis with nail incarnation: case series, complex surgical treatment. Bull. Sci. Res., 4, 56-60.
15. Vergun, A.R. (2018). Surgical nail pathology: some problems of diagnosis and complex treatment. Doctor's thesis. Lviv: Danylo Halytsky Lviv National Medical University of Ministry of Health of Ukraine.

16. Yabe, T., \& Takahashi, M. (2010). A minimally invasive surgical approach for ingrown toenails: partial germinal matrix excision using operative microscope. J. Plast. Reconstr. Aesthet. Surg., 63 (1), 170-173.

17. Zaias, N., Escovar, S.X., \& Zaiac, M.N. (2015). Finger and toenail onycholysis. J. Eur. Acad. Dermatol. Venereol., 29 (5), 848-853. 18. Zang, K., Sullivan, R., \& Shanks, S. (2017). A retrospective study of non-thermal laser therapy for the treatment of toenail nychomycosis. J. Clin. Aesthet. Dermatol., 10 (5), 24-30.

19. Zavala Aguilar, K., Gutierrez Pineda, F., \& Bozalongo de Aragon, E. (2013). Management of onychocryptosis in primary care: A clinical case. Semergen, 39 (6), 38-40.

20. Zecha, M., Alsina, M., Tortes Rodriquez, J.M. (2001). Combination of amorolfine nail lacquer and oral itraconazole: a new approach for the treatment of severe onychomycosis. JEADV, 5, 67. 21. Zeichner, J.A. (2015). Onychomycosis to fungal superinfection: Prevention strategies and considerations. J. Drugs Dermatol., 14 (10), 32-34.

22. Zeng, M., \& Fu, S.P. (2012). Meliorated surgical procedure of Winograd for recurrent onychocryptosis. Zhonghua Yi Xue Za Zhi., 92 (25), 1767-1769.

\section{PURULENT-NECROTIC SURGICAL ONYCHOPATOLOGY (NAIL PATHOLOGY), AUTHOR'S VIEW: SOME PROBLEMS OF DIAGNOSTICS AND COMPLEX TREATMENT OF COMPLICATED AND COMBINED CASES}

The aim of the work: to research and improve the effectiveness of complex treatment of chronic and combined purulent-necrotic pathology of the distal hands and foot, in particular "surgical onychopathology", by optimizing clinical diagnosis, development of individual sequences of complex surgical procedure, creating effective schemes of anti-relapse measures and prevention of secondary incarnations. Materials and Methods. The research was performed at Danylo Halytskyi Lviv National Medical University clinical bases. Over a 15year period (2006-2020) in 1838 patients, 5-92 years old, 1007 men and 831 women some nosological forms, clinical variants and features of the pathological process were studied. 757 cases of onychodestruction were prospectively investigated. Clinical and morphological material by classical (descriptive) and correlation statistics methods were processed. The design of the study included the adherence to the principles of confidentiality and respect for the patient's personality, the concept of informed consent and other provisions, clauses of moral and ethical norms and principles of bioethics.

Results and Discussion. The largest observations of non-mycotic and mycotic-associated purulent-necrotic chronic and combined pathology of the hand and foot a subset of middle-aged people were stated. The age distribution showed a prevalence (in total samples) of middle-aged and elderly people, especially in sub-samples with mycotic dermatophyte (trichophytic) lesions. Recurrence ingrown toenails and subungual hyperkeratosis with secondary nail ingrowth determined due to compression by hyperkeratoid masses and dermatophytoma of the central part of the nail, deformity and incarnation in patients 50-70 years old were diagnosed. $45.05 \%$ of cases of ingrown nails were approved and $21.87 \%$ - complicated dermatophytic onychomycosis. Some purulent combined cases and necrotic variants of onychodestruction, as well as polyonychomycosis that are typical for elderly and senile patients $\left(\mathrm{x}^{2}=24.12, \mathrm{p}=0.028\right)$ were stated. Most cases in patients with complicated onychomycosis $\left(\chi^{2}=20.87, p<0.01\right)$ with secondary deformity of mycotically altered nail $\left(\chi^{2}=17.35, p=0.022\right)$, some nail ingrowth in soft tissue $\left(X^{2}=15.36, p<0.05\right)$ were diagnosed. In $48 \%$ of mycotic lesions subsamples were incurved and ingrowing the one nail, $27 \%$ - two nails, in the other $25 \%$ of the partial prospective sample - more than 2 nail plates. During the pathomorphological study, some complicated, torpid, chronic variants, as well as recurrent cases of some purulent-necrotic pathology of the hand and foot, patho- and morphogenesis of destructive onychomycosis were simultaneously studied and specified. Secondary infection, joining the my- 


\section{З ДОСВІДУ РОБОТИ}

cotic "surgical onychopathology", bacterial superinfection etc determines the formation of low- or asymptomatic subungual panaritium of mixed etiology. Secondary chronic osteomyelitis of the distal phalanx was found in $5 \%$ of all inpatients. A significant cases of unsatisfactory treatment results in combined lesions is determined by inadequate choice or technical violations (mistakes) of surgical procedure, in cases of leaving some nail spicules and unsuccessful resection $\left(x^{2}=4.22\right)$. Some recurrence when Dupuytren's method of removing nails and other known surgical procedure $\left(\chi^{2}=13.47, p=0.02\right)$, at refusal of carrying out simultaneous interventions on paronychial and subungual structures were observed. Surgical treatment should include anti-incarnation corrective measures, $\chi^{2}=12,11, p=0.024$; which significantly reduces the risk of recurrence, $\chi^{2}=28.17, p<0.01$. Block-shaped eponychectomy, some methods of minimally invasive affected nails mobilization and dissection were proposed and implemented. The maximum recurrence rate of polyonychomycosis was observed within 12-15 months, $\chi^{2}=25.52$, $p=0.018$, in the case of systemic therapy - for the third year after treatment, $\chi^{2}=13.47, p=0.023$. Removal of affected nails in patients with destructive complicated onychomycosis, combined lesions should be performed through onycholized structures.

Key words: purulent-necrotic onychopathology; onychomycosis; nail incarnation; combined lesions; morphogenesis; complications; complex surgical treatment. 